\title{
Long-term fishing impact on the Senegalese coastal demersal resources: diagnosing from stock assessment models
}

\author{
Kamarel Ba ${ }^{1,2, *}$, Modou Thiaw ${ }^{1}$, Massal Fall ${ }^{1}$, Ndiaga Thiam ${ }^{1}$, Beyah Meissa ${ }^{3}$, Didier Jouffre ${ }^{4}$ \\ Omar Thiom Thiaw ${ }^{2}$ and Didier Gascuel ${ }^{5}$ \\ ${ }^{1}$ CRODT, ISRA-Sénégal, Pôle de Recherche de l'ISRA/Hann, 2241 Dakar, Sénégal \\ 2 Université Cheikh Anta DIOP, Faculté des Sciences et Techniques, Département de Biologie animale, 5005 Dakar, Senegal \\ ${ }^{3}$ Institut Mauritanien de Recherches Océanographiques et des Pêches (IMROP), 22 Nouadhibou, Mauritanie \\ ${ }^{4}$ Institut de Recherche pour le Développement (IRD), Unité MARBEC, Université de Montpellier, Place E. Bataillon, \\ 34095 Montpellier cedex 5, France \\ ${ }^{5}$ Université Bretagne Loire, Agrocampus Ouest, UMR985 Ecology and Ecosystems Health, 65 rue de Saint Brieuc, \\ CS 84215, 35042 Rennes cedex, France
}

Received 1 March 2017 / Accepted 24 November 2017

Guest Editor: Jörn Schmidt

\begin{abstract}
For the first time in Senegal, assessments based on both stochastic and deterministic production models were used to draw a global diagnosis of the fishing impact on coastal demersal stocks. Based one national fisheries databases and scientific trawl surveys data: (i) trends in landings since 1971 were examined, (ii) abundance indices of 10 stocks were estimated using linear models fitted to surveys data and commercial catch per unit efforts, and (iii) stock assessments were carried out using pseudo-equilibrium Fox and Pella-Tomlinson models and a Biomass dynamic production model fitted in a Bayesian framework to abundance indices. Most stocks have seen their abundance sharply declining over time. All stocks combined, results of stock assessments suggest a 63\% reduction compared to virgin state. Three fifth of demersal stocks are overexploited and excess in fishing effort was estimated until $75 \%$ for the worst case. We conclude by suggesting that the fishing of such species must be regulated and an ecosystem approach to fisheries management should be implemented in order to monitor the whole ecosystem.
\end{abstract}

Keywords: Coastal demersal species / delta-GLM models / surplus production models / Bayesian approach / overexploitation / West Africa

\section{Introduction}

The North-West African region has experienced rapid development of coastal demersal fisheries over the past four decades. Consequently, the biomass of many coastal demersal stocks has drastically fallen and alarming signs of overfishing are currently known (Gascuel et al., 2004, 2007; Christensen et al., 2004; CECAF, 2012). In Senegal, the catches peaked in the mid-1980s before reducing the decade after while the fish biomasses severely declined in response to a very heavy overexploitation (Laurans et al., 2003; Gascuel et al., 2003; Thiam et al., 2014, 2016). The fishing pressure is due to smallscale and industrial fleets, which have developed since the 1950s and 1970s, respectively. Both fleets exploit demersal

*Corresponding author: kamarel2@hotmail.com fish over the entire continental shelf (Garcia et al., 1979; Ba et al., 2016).

The Senegalese continental shelf was about $196000 \mathrm{~km}^{2}$, and the coastline was $718 \mathrm{~km}$ (Fig. 1). The waters are rich in fishing resources given their particular hydrodynamics (Faure et al., 2000) and their favorable geomorphology and climate (Roy et al., 2002). The coastal demersal species are essentially found throughout the southern Mediterranean and along the western coast of Africa, from Gibraltar (Spain) to the southern coast of Angola. Adults live on rocky, muddy or sandy bottoms in depths of 20-200 m, whereas juveniles are captured in coastal lagoons and estuaries and on the coastal fringe. In Senegal, the coastal demersal species have usually high commercial values, and provide large exports and incomes. They are mainly fished by motorized artisanal pirogues using hand-lines but also fixed bottom net, and industrial trawlers.

The coastal demersal fishes are known for their low growth rates, late sexual maturity, low fecundity and a high 


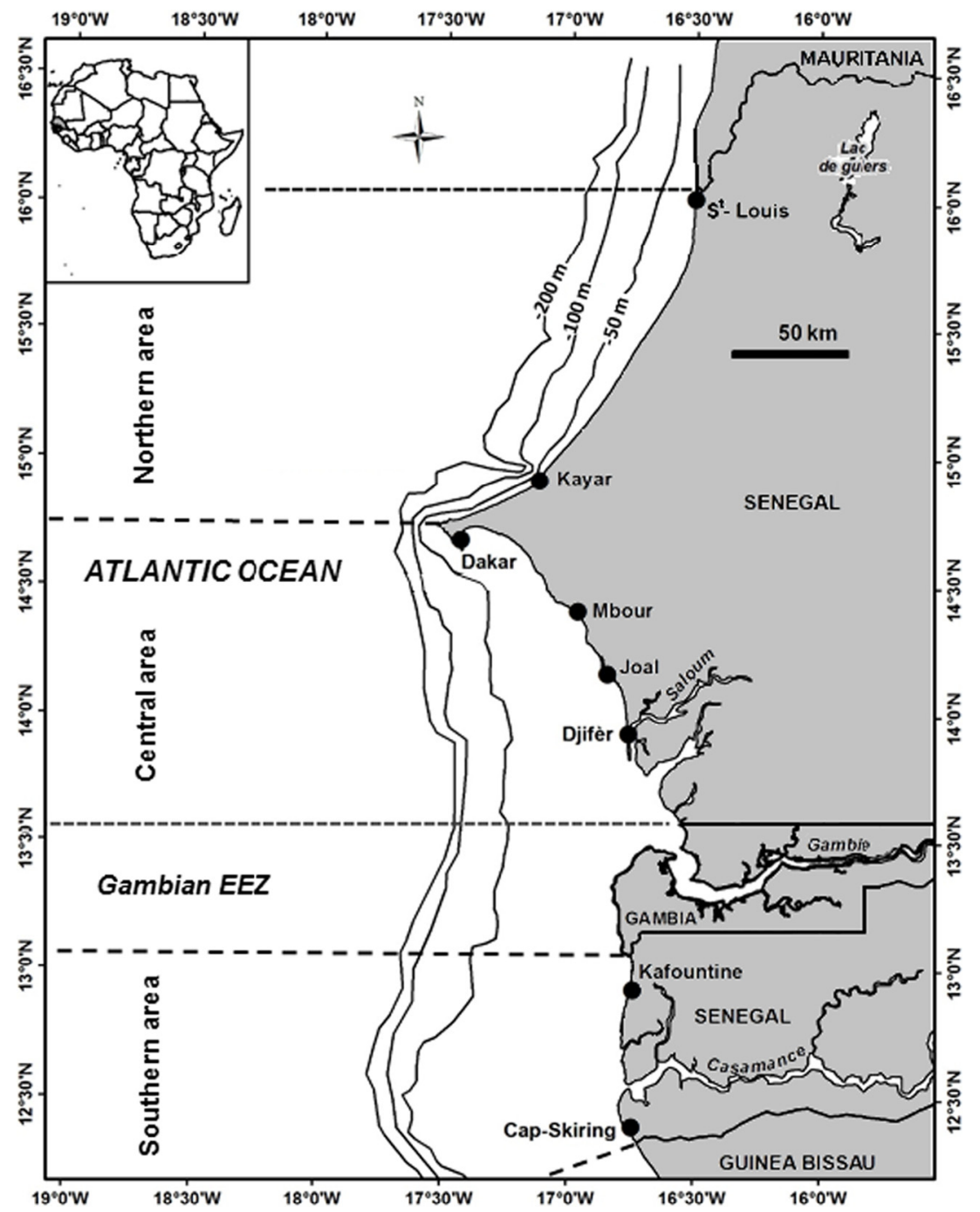

Fig. 1. Map of the study area. Saint-Louis, Kayar, Dakar (consisting in Yoff, Ouakam, Soumbédioune, Maritime Port of Dakar and Hann), Mbour, Joal, Djifer and Kafountine are landing ports covered by CRODT statistical information system. Maritime areas refer to the zoning used for the industrial fishery. Gambian EEZ was not taking into account in the study, neither were Mauritanian EEZ and Bissau Guinean EEZ.

vulnerability/sensibility to fishing (Gislason and Rice, 1998). The assessments of five coastal demersal fish stocks considered as key indicator species (Epinephelus aeneus, Pagellus bellottii, Galeoides decadactylus, Pseudupeneus prayensis and Sparus caeruleostictus) indicates a fourfold decline in abundance between 1983 and 1998 (Barry et al., 2002; Gascuel et al., 2003; Laurans, 2005). More recent stock assessments confirmed that four of this five stocks were overexploited (Barry et al., 2002; Laurans, 2005; Thiaw et al., 2015; Meissa et al., 2016), with a diagnosis of recruitment overfishing for E. aeneus, and P. bellottii, therefore threatened with collapse.

Thus far, all past stock assessments were performed with surplus production models using deterministic equations and a pseudo-equilibrium approach (Gascuel, 2008). Although criticized by (Hilborn and Walters, 1992), these production models are still in use due their robustness and quick application (Fonteneau et al., 1998; Gascuel, 2008; Meissa et al., 2013). Such deterministic models represent only the mean biological parameters, and the behavior expected of a system in the absence of random variations. In contrast, stochastic models incorporate noise or randomness in some way (Bolker, 2008). In particular, Bayesian approaches has been widely applied in fisheries sciences since the 1990s (Walters and Ludwig, 1994; Punt and Hilborn, 1997; McAllister and Kirkwood, 1998; Harwood and Stokes, 2003). It allows the integration of different types of information (Hilborn and Liermann, 1998) and multiple sources of uncertainty in data and models (Robert et al., 2010). It thus provides uncertainty estimates around the exploitation indicators.

For the first time in Senegal, in parallel to the biomass production model based on pseudo-equilibrium hypothesis, we used a dynamic and stochastic model, fitted in a Bayesian framework (Ono et al., 2012; Meissa et al., 2013; Meissa and Gascuel, 2014).

All assessments performed will help us to better analyze changes in the abundance of the Senegalese coastal demersal fish stocks. In our study, we aim to: (1) quantify the impact of fishing on coastal demersal fish stocks, (2) establish the 
Table 1. Type of variable inputs for delta-GLM models.

\begin{tabular}{ll}
\hline Type of data & Variables used in the delta-GLM \\
\hline Industrial fishing CPUE & Year (1971-2013), Month (January to December), fishing area (Northern area, Central area and \\
& Southern area), engine power (less than $250 \mathrm{cv}, 251-500,501-1000,1001-2000$ and more than \\
& $2000 \mathrm{cv})$, GRT (less than 50, 51-150, 151-250, 251-500, more than 500) \\
Small-scale fishing CPUE & Year (1974-2013), Month (January to December), landing harbor (Saint-Louis, Kayar, Yoff, \\
& Ouakam, Soumbédioune, Hann, Mbour and Joal), gear (handline or fixed bottom net) \\
Scientific survey & Year (1986-2008), season (cold: November-May; hot: June-October), area (Northern area, \\
& Central area and Southern area), depth (10-25 m, 26-50 m, 51-100 m, 101-200 m) \\
\hline
\end{tabular}

diagnosis of the status of demersal resources, and (3) identify the most sensitive species to fishing pressure which should be considered in priority for ecosystem approach to fisheries management.

First, yearly abundance indices were estimated using deltageneralized linear model (GLM) from both data sources, the commercial statistics (1971-2013) and the scientific trawl surveys performed on the Senegalese continental shelf during the 1986-2008 period. Then, surplus production models were fitted to data, revealing the impact of fishing on stock abundance and changes induced by fishing in the demersal community. Results are discussed from a fisheries management perspective.

\section{Material and methods}

\subsection{Data used}

Two types of fisheries data managed by the oceanographic research centre of dakar-thiaroye (CRODT, Centre de Recherches Océanographiques de Dakar-Thiaroye) since 1971 were used (Tab. 1):

- The industrial fishery database refers to all industrial vessels landing in the Maritime Port of Dakar (Fig. 1) and includes the number of days at sea and the catch over the 1971-2013 period. These data were aggregated per year, month, fishing area, and vessel (each characterized by its engine power and gross registered tonnage, GRT). Catches per unit effort (in kilogram per fishing day) were used to estimate abundance indices for each fish stock (Laurans, 2005);

- For the small-scale fishery, the database includes the catch and the number of fishing trips, per year month, landing harbour, and fishing gear, over the 1974-2013 period. Eight main landing harbours were sampled: Saint-Louis, Kayar, Yoff, Ouakam, Soumbédioune, Hann, Mbour and Joal (Fig. 1). The catch per unit effort (CPUE) were calculated in kilograms per fishing trip and used to estimate the yearly abundance indices of the coastal demersal fish stocks. This effort represents the number of fishing trips performed in a given fishing area using the main fishing gears (hand-line and fixed bottom net).

Since 1970, scientific surveys were conducted on the Senegalese continental shelf. While the oldest ones mainly focused on the study of fish biology, since the 1980s these surveys aim to provide a fishery-independent measure of fish distribution and abundance of all the species that can be sampled by bottom trawl (Laurans et al., 2004; Fall, 2009). Twenty-five surveys covering the whole continental shelf, from 10 to $200 \mathrm{~m}$ deep, and using the same sampling protocol were considered in the current analyses (sampling design of the surveys are described in (Laurans et al., 2004; Fall, 2009; Thiaw, 2010). They are covering a 23 years period of time, from 1986 to 2008 (with five missing years; 1996, 2000, 2002, 2006 and 2007), and gather 2633 hauls. Catches per trawl haul (30 $\mathrm{min}$ ) were used to estimate survey abundance index.

\subsection{Species selection}

Among demersal species, 10 taxa or species were selected according to three criteria: (i) their high social and economic values, (ii) the importance of landings and (iii) the availability of reliable information to estimate their abundance. The selected taxa only included demersal fishes and accounted for $23 \%$ of total landings in Senegal and for around $50 \%$ of demersal catches (42 $000 \mathrm{t}$ in average for the last decade 20032013) with a small-scale fishery contribution of $78 \%$ (Fig. 2).

The species selected included the white grouper or "thiof" (E. aeneus), the red pandora ( $P$. bellottii), the bluespotted seabream (Pagrus caeruleostictus), the African lesser $(G$. decadactylus), the goatfish or red mullet (P. prayensis), and the rubberlip grunt (Plectorhinchus mediterraneus). For four genera, the determination down to species level is only available in small-scale fishery database, and still uncertain in industrial catch database because stored in a species common name. For these species, the assessments were thus performed at the genus level. These four taxa were the tonguesoles (Cynoglossus spp., consisting in Cynoglossus canariensis and C. senegalensis), the smooth-mouth sea catfish also known as Arius spp. (dominated by Carlarius heudelotii, also including Arius parkii and A. latiscutatus, ), the snappers (Lutjanus spp.), and other groupers (Epinephelus spp.), excluding the Thiof.

\subsection{Abundance indices and fishing effort}

For each species or taxon, three series of annual abundance indices were estimated using a delta-GLM (Stefánsson, 1996; Meissa et al., 2013); two from CPUEs of the small-scale and the industrial fisheries, and the last one from scientific surveys. This model has also been well described and applied in many 


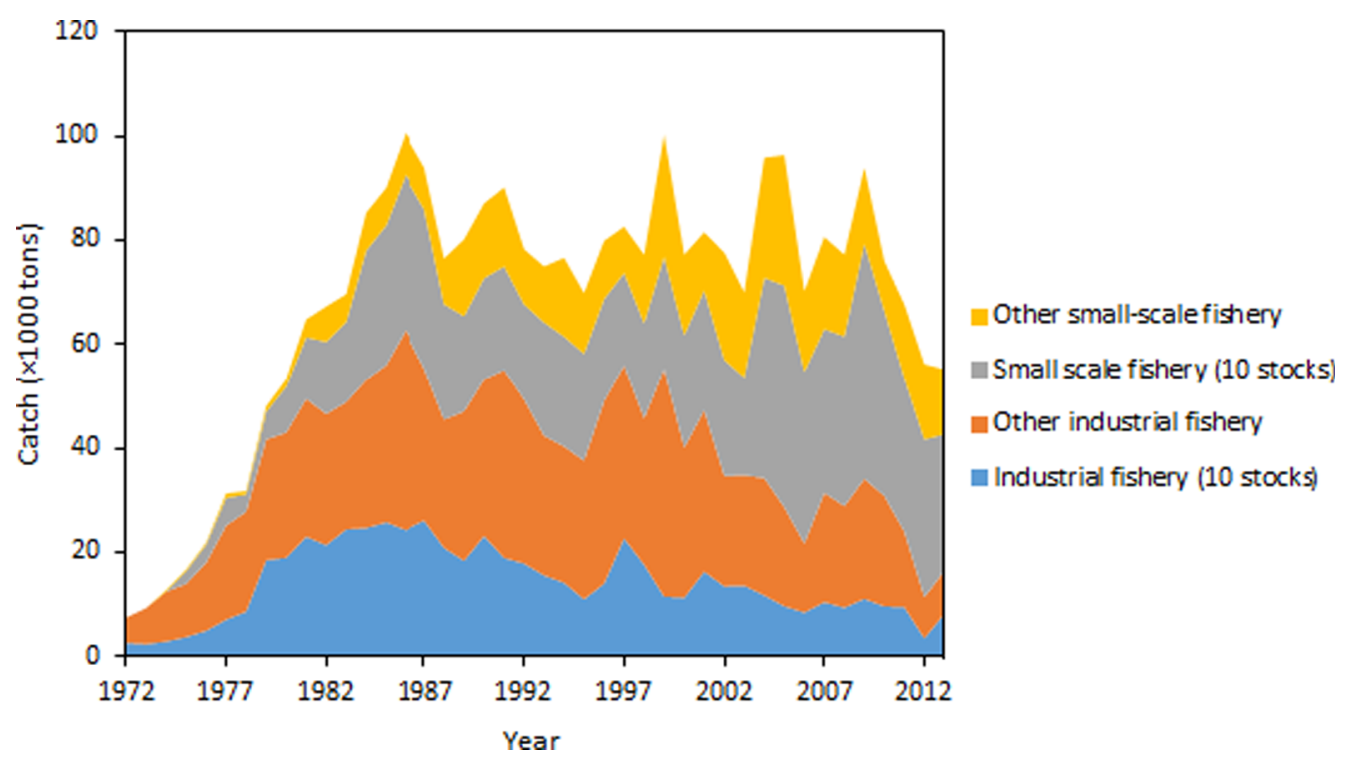

Fig. 2. Catches of coastal demersal fisheries per fishing sector: industrial ( 10 stocks) and small-scale ( 10 stocks) fisheries are used in this study while the other industrial and small-scale fisheries represent all demersal stocks not included in our stock or complexes stocks selection.

studies estimating the annual abundance indices of fish stocks (Laurans, 2005; Thiaw et al., 2009; Thiaw, 2010; Meissa et al., 2013; Meissa and Gascuel, 2014; Thiam et al., 2014, 2016).

The model is the product of a binomial GLM sub-model, which estimates the presence/absence probability of each taxon/species during a sea-trip or trawl haul and a Gaussian GLM sub-model on log-transformed non-null values of raw CPUE or densities per trawls corrected with Laurent (1963) formula in order to obtain unbiased values of the expected abundance index (for more details, see Meissa et al., (2013)).

In the calculation of abundance indices using the deltaGLM model, the effects of variables "year", "month", "fishing area", "engine power" and "GRT" were incorporated into models for industrial fishing sector (Tab. 1 and Tabs. S1-S5). While the effects of variables "year", "month", "landing harbor" and "gear" were tested for small-scale fishing sector. The inputs variables for scientific survey abundance indices were "year", "season", "area" and "depth". For each model, the variables with significant deviances were retained in the estimation of abundance indices (Tab. S6).

Based on expert knowledge (Meissa et al., 2013; Meissa and Gascuel, 2014), the abundance indices from commercial CPUE were finally corrected by assuming a yearly increase of mean fishing power $\alpha$ :

$$
A I_{i}=\frac{\text { AIcommercial }, i}{(1+\alpha)^{i-i}}
$$

where: $A I_{\text {commercial, } i}$ is the raw index of abundance estimated from commercial data for year $i ; A I_{i}$ is the corrected index for year $i$ and $\alpha$ is the annual rate of increase of the fishing power of the related commercial fishery (Gascuel et al., 1993).
This increase is linked to the modernization of the Senegalese fleets (artisanal and industrial fishing) throughout the years, especially fishers who now are equipped with GPS, large iceboxes and powerful outboard engines (Thiao et al., 2012).

Sensitivity analyses (see Supporting materials) were performed on the abundance indices by giving $\alpha$ values between 0 (optimistic case) and 6\% (pessimistic case) (Gascuel and Ménard, 1997; Meissa et al., 2013). Then each series of corrected abundance index from industrial or smallscale fishery was correlated with survey abundance index. Then, the best abundance index (highest correlation) was retained, covering the whole 1971-2013 period and used as the reference input in stock assessment models.

Yearly values of the fishing effort were expressed as a fishing effort multiplier $(m E)$ using the mean of the last three years as a reference value $(m E=1)$. It was calculated from the total catch $(Y)$ as follows:

$$
m E_{i}=\frac{Y_{i}}{A I_{i}} \times \frac{\overline{A I_{2011 \rightarrow 2013}}}{\overline{Y_{2011 \rightarrow 2013}}},
$$

where $i$ refers to year, $\overline{A I_{2011 \rightarrow 2013}}$ and $\overline{Y_{2011 \rightarrow 2013}}$ are the mean abundance index and catch over the 2011-2013 period.

Then, a Fox effort multiplier $\left(m E_{i, p}\right)$ was calculated. It expresses the cumulative fishing pressure applied to the stock, based on the idea that among the $\mathrm{p}$ age-classes exploited in year $\mathrm{i}$ with a fishing effort $m E_{i},(p-1)$ were already present in year $i-1$ and were exploited with a fishing effort $m E_{i-1},(p-2)$ were already there in year $i-2$ and exploited with $m E_{i-2}$, etc. (Fox, 1975; Gascuel, 2008). The Fox effort is expressed as follows:

$$
m E_{i, p}=\frac{p \times m E_{i}+(p-1) \times m E_{i-1}+(p-2) \times m E_{i-2}+\cdots+(p-(p-1)) \times m E_{i-p}}{p+(p-1)+(p-2)+\cdots+(p-(p-1))} .
$$


Generally, demersal finfishes have long lifespan thus a value $p=5$ was conventionally taken.

\subsection{Stock assessment models}

Surplus production models are simple and common models often used for stock assessment purposes. They assume that a population's capacity to increase is a function of the population density and this latter will not change if individuals are removed at the same rate as the population's capacity to increase (Jensen, 2005). In the present study, two types of surplus production models were applied: (1) a pseudo-equilibrium production model and (2) a dynamic production model.

\subsubsection{Equilibrium production model}

In the equilibrium production model, abundance of the stock is expressed as a function of fishing effort. Schaefer (1991) showed that if the fishery effort remains constant, the stock progressively tends towards its equilibrium state regardless of its initial situation. The catches at pseudoequilibrium for the Fox (1970) and Pella and Tomlinson (1969) models were respectively defined by:

$$
\begin{gathered}
Y_{e}\left(m E_{i}\right)=b \times m E_{i} \times e^{-a \times m E i}, \\
Y_{e}\left(m \mathrm{E}_{i}\right)=m \mathrm{E}_{i} \times\left(a \times m \mathrm{E}_{i}+b\right)^{\frac{1}{m-1}} .
\end{gathered}
$$

The Pella-Tomlinson model and the Fox model can be fitted to abundance and fishing effort data using the pseudoequilibrium method (Fox, 1975; Fonteneau et al., 1998; Gascuel, 2008). This method assumes that the stock abundance observed in year $i\left(A I_{i}\right)$ is in equilibrium with a the Fox multiplier fishing effort values $m E_{i, p}$, which measures the cumulative effort of the $p$ previous years on the stock. Thus, the abundance index is expressed for the Fox and Pella and Tomlinson models, respectively as:

$$
\begin{gathered}
A I_{i}\left(m E_{i}\right)=b \times e^{a \times m E_{i}}, \\
A I_{i}\left(m E_{i}\right)=\left(a \times m E_{i}+b\right)^{\frac{1}{m-1}},
\end{gathered}
$$

where $\left(a=-\frac{q \times \ln K}{K} ; b=q \times K\right)$ for the Fox model and $\left(a=\frac{q}{r} \times(q \times K)^{r-1} ; b=(q \times K)^{m-1}\right)$ for the Pella and Tomlinson model, $q$ the catchability, $r$ the intrinsic growth rate and $K$ the carrying capacity of the stock. The "a" and "b" parameters were estimated by fitting models to the time series of the $A I_{i}$ and $m E_{i}$ using equations 5 and 6 and the maximum likelihood method assuming that residuals are independent and identically log-normally distributed (Meissa et al., 2013).

\subsubsection{Biomass dynamic production model}

The biomass dynamic model relaxes the hypothesis of pseudo-equilibrium, but more parameters are estimated (Gascuel, 2008). The model was expressed on an annual time step, and implemented within a stochastic state-space framework (Meyer and Millar, 1999; McAllister et al., 2001; Ono et al., 2012). The stochastic process deduces the biomass $B$ at year $i+1$ from the biomass at year " $i$ " $\left(B_{i}\right)$, taking into account a process error around the dynamic equation of the model:

$$
B_{i+1}=\left(B_{i}+g\left(B_{i}\right)-Y_{i}\right) \times e^{1^{(i)}},
$$

where $Y i$ is the observed catch during the year $i, g(B i)$ is the production function and $e^{\epsilon_{1}}(i)$ is the multiplicative log-normal process error, with ${ }_{1}(i) \sim N\left(0, \sigma_{P}^{2}\right)$. In the case of the dynamic model, over-parametrization is often problematic, leading to unreliable results. Therefore, we only considered the Fox (1970) production function $\left(g\left(B_{i}\right)=r \times B_{i} \times\left(1-\frac{B_{i}}{K}\right)\right)$, whose parameters number is lower than the Pella-Tomlinson function (2 and 3, respectively).

The model was fitted to the estimated abundance indices assuming a lognormal distribution of observation errors:

$$
A I_{i}\left(m E_{i}\right)=q \times B_{i} \times e^{\varepsilon_{2}(i)},
$$

where $q$ is the catchability and $e^{\epsilon_{2}}(i)$ is an observation error, with $_{2}(i) \sim N\left(0, \sigma_{\text {obs }}^{2}\right)$. The ratio of the process and observation error variance was taken to be 1 (i.e. $\sigma_{p}^{2}=\sigma_{o b s}^{2}=\sigma^{2}$ ) (Robert et al., 2010; Ono et al., 2012; Meissa et al., 2013; Meissa and Gascuel, 2014) and constraints on parameter values (K, $r$ and $q$ ) of the Fox model were introduced as prior probabilities in the framework of Bayesian adjustment.

Since the industrial demersal fleets began around 1950 and quickly developed between the 1960-1970 period with an extension to the entire West African coast (Garcia et al., 1979), we assumed that the biomass at the beginning of the time series is a proportion of the carrying capacity $K$. Then to be consistent with (8), the biomass of the first year $\left(B_{1}=K \times e^{\epsilon_{1}}\right)$ was considered as lognormally distributed around the carrying capacity (Parent and Rivot, 2012). The other priors used in analyses for the parameters $K, \log (q), r$ and $\log \left(\sigma^{2}\right)$ were assumed to be uniformly distributed.

The curve of equilibrium catch corresponding to the parameters of the dynamic model was drawn from the joint posterior distribution (for more details, see Ono et al., 2012; Meissa et al., 2013). The parameters for fishing mortality were computed a posteriori:

1 fishing mortality at the current fishing level: $F=\frac{\text { Catches }}{\text { Biomass }}$;

2 fishing mortality at $M S Y: F_{M S Y}=\frac{M S Y}{B_{Y S Y}}$, where $M S Y$ and $B_{M S Y}$ are maximum sustainable yield and biomass at $M S Y$.

Bayesian posterior distributions of all model parameters and variables (e.g. biomass time-series) were computed via monte-carlo markov-chain (MCMC) methods using the $\mathrm{R}$ packages BRugs and Coda. Three independent MCMC chains with dispersed initialization points were used. The first 10000 iterations of each chain were discarded.

Inferences were derived from a sample of $3 \times 50000$ iterations after a "burn-in" period. One out of ten iterations was kept to reduce MCMC sampling autocorrelation (Meissa and Gascuel, 2014) and the convergence of MCMC sampling was checked using Gelman-Rubin test for all posterior (Brooks and Gelman, 1998). Goodness-of-fit was assessed using the coefficient of determination $R^{2}$ between predicted and observed abundance index.

The status of each stock was determined using a Kobe plot which represents $B / B_{M S Y}$ and $F / F_{M S Y}$ in a figure with 4 quadrants according to the stock status (stock under-exploited or overexploited, according to $B / B M S Y$ ) and to the fishing 


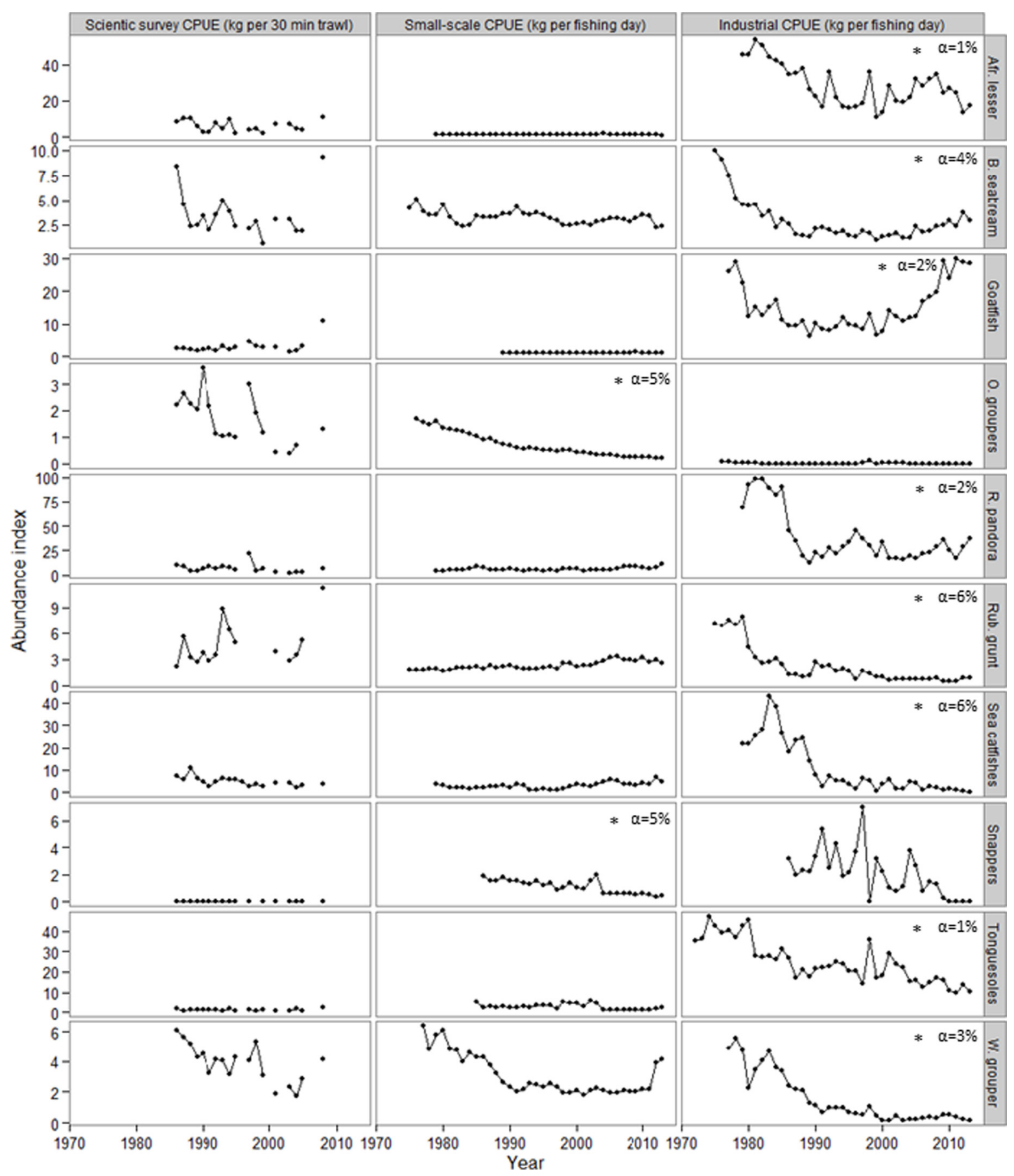

Fig. 3. Trends in the demersal stocks abundances; indices estimated using delta-GLM fitted to scientific survey yields and commercial CPUEs (artisanal and industrial). The annual rate of increase in fishing power is presented by alpha $(\alpha)$ in the top-right corner of each panel and the star $\left.{ }^{*}\right)$ on this left, indicate the commercial index used to fit surplus production models.

pressure (experiencing overfishing or not, according to $\mathrm{F}$ / FMSY) (Arrizabalaga et al., 2012).

Finally, any possible retrospective pattern (systematic inconsistencies among our model estimates of biomass and fishing mortality rate based on increasing periods of data) was tested by sequentially removing the most recent year of data going back 5 years and estimated biomass and fishing mortality rates were compared (Legault, 2009; Yau et al., 2014).

\section{Results}

\subsection{Abundance indices}

The delta-GLMs fitted to commercial CPUEs and to scientific surveys data provide consistent trends of taxa abundances over the studied period (Fig. 3, Tabs. S1-S5). For most taxa, abundance indices computed from the industrial fishery are the most correlated with abundance index from 
scientific surveys (Tab. S6). The others groupers (white grouper excluded) and the snappers are exception, with their abundance indices calculated from motorized artisanal pirogues using hand-line and fixed bottom net, respectively.

Models fitted to small-scale CPUEs (Tab. S1) explain between $14 \%$ and $57 \%$ of the total deviance, according to species or taxa. The retained explanatory variables do not explain the majority of the deviance except for the bluespotted seabream $(57 \%)$. In the explained deviance, the "Harbor" effect take the most important part (8.8-50.2\%) showing that fishers have spatialized the fishing effort along the coast. The "year" effect is in second position in terms of contribution in the explained deviance $(0.2-18.4 \%)$, reflecting a year-to-year variability in abundance. The "Month" effect (0.3-7.7\%) shows a less seasonal marked variation in abundance.

For industrial fishing data, the explained deviances of binomial (Tab. S2) and Gaussian models outputs (Tab. S3) are in $4-45.8 \%$ and $9.1-39.2 \%$ ranges, respectively. The significant effects which account for the higher contribution in models (for all species/taxa) were those of "Year" and "Fishing area". This highlights contrasted abundances of demersal fish between areas and years. The seasonal effect (although significant) was less marked for all species.

As for industrial fishing, the binomial model applied to scientific survey data (incorporating all independent variables) explains deviances varying from 16 to $40.5 \%$. Overall, the "Depth" effect is the most important in term of explained deviances, followed by the "Area" effect and the "Year" effect, while deviance explained by the "Season effect" is small. Consequently, the occurrence of demersal species depends especially of the bottom depth and areas. The results of Gaussian model explain 9.2 to $26.1 \%$ of deviance according to species/taxa (Tab. S5). The "Year" effect contributed in large part to the explained deviances, showing a year-to-year variation of species abundance in surveys. Meanwhile, the "Depth" and "Area" effects also contribute significantly in deviance reduction, highlighting that demersal fish abundance is affected by depth and spatial distribution.

Scientific surveys reveal that the abundance of the red pandora is the highest $(6.8 \mathrm{~kg} / 30 \mathrm{~min}$ of trawling on average) with a peak of $22 \mathrm{~kg} / 30 \mathrm{~min}$ of trawling in 1997 . The African lesser, the smooth-mouth sea catfishes and the rubberlip grunt occupy the second, third and fourth positions with $6,4.8$ and $4.7 \mathrm{~kg} / 30 \mathrm{~min}$ of trawling on average, respectively. The other fish stocks are encountered in trawl less than $4 \mathrm{~kg} / 30 \mathrm{~min}$ on average (Fig. 3). Nevertheless, scientific surveys also show a high year-to-year variability in abundance for all demersal species/taxa with peaks occurring during some years.

Sensitive analyses performed on commercial indices (by varying $\alpha$, the rate of yearly increase in the fishing power of vessels or pirogues) show that scientific survey indices have similar trends with commercial CPUEs and are significantly correlated especially for industrial fishing abundance indices (Tab. S6). The snappers and the others groupers are exception; their abundance indices derived from the craftsmen fishers' CPUE using fixed bottom net and hand-line respectively, are significantly correlated and higher ( $\alpha=5 \%$ each).

Abundance indices estimated from commercial CPUE (Fig. 3) exhibit a clear decreasing trend for almost all taxa except for the goatfish which abundance strongly increased since 2000. Also, the African lesser, the bluespotted seabream and the red pandora abundances increased a bit, but onwards 2000 only. The situation of these three species is similar: strong abundance indices at the beginning (before 1980) followed by a sudden drop with minimum values at the end of the 1980s. The 1990-2000 period is trendless, although some year to year variabilities in abundance indices is observed.

The smooth-mouth sea catfishes, the tonguesoles and the snappers abundance indices show decreasing "sawtooth shaped" trends since 1980 demonstrating a high variability in abundance. The abundance indices of the rubberlip grunt, the white grouper and the others groupers also dropped quickly over years without signs of recovery. Comparing the recent period to the beginning of the exploitation, the total decrease of the ten altogether reaches more than $72 \%$. The decrease is more pronounced (94\%) if we consider the six stocks for which their abundance did not increase in the recent years.

\subsection{Catches trends}

Among ten demersal fish stocks and stock complexes, the African lesser and the goatfish are mainly caught by industrial fishery (68\% and $96 \%$, respectively), while the small-scale fishing sector contributed to $79 \%$ of the white grouper total catches, $99 \%$ of the other groupers (excluding the white grouper), $93 \%$ of the snappers and $81 \%$ of rubberlip grunt, considering the entire series (Fig. S1).

Cumulative catches of all coastal demersal fishes considered (Fig. 4a) show a fast increase between the 1970s and the mid-1980s with a peak of 57000 metric tons in 1987. A sudden drop in catches occurs at the end of the 1980s (from 57000 t to $37000 \mathrm{t}$ ). Then, landings tended to stabilize around $36000 \mathrm{t}$ during the 1990-2000 period. The last ten years are characterized by a small increase in catches (an average of $44000 \mathrm{t}$ ) with two peaks $(52000 \mathrm{t}$ and $56000 \mathrm{t}$ in 2005 and 2009, respectively).

Among the 10 species/taxa, the smooth-mouth sea catfish is the largest in weight ( $20.6 \%$ on average over the period). Then come in second position the African lesser which contributes for $17.2 \%$, the tonguesoles occupied the third place with $16.8 \%$ of total catch. The other taxa catches contribution were less than $11 \%$ (the red pandora $=10.4 \%$, the bluespotted seabream $=9.5 \%$, the rubberlip grunt $=9.2 \%$, the other groupers $=6.8 \%$, the white grouper $=4.1 \%$, the goatfish $=4.0 \%$ and the snappers $=1.4 \%$ ).

\subsection{Stock assessment}

The equilibrium and dynamic production models both fit well to abundance indices estimated from commercial CPUE, with significant correlations between observed and predicted abundance indices. A comparison between models show that Pella-Tomlinson generalized models are very close to Fox models. The correlation $\left(R^{2}\right)$ between the observed abundance indices and those predicted are a bit higher for the stochastic Fox models than for the deterministic (Fox and PellaTomlinson) ones (Tab. 2 and Tab. 3). Thus, the retained model which our figures and results focused on is the dynamic production Fox model.

The estimated key model parameters from the Bayesian state-space production model are shown in Table 3. The 

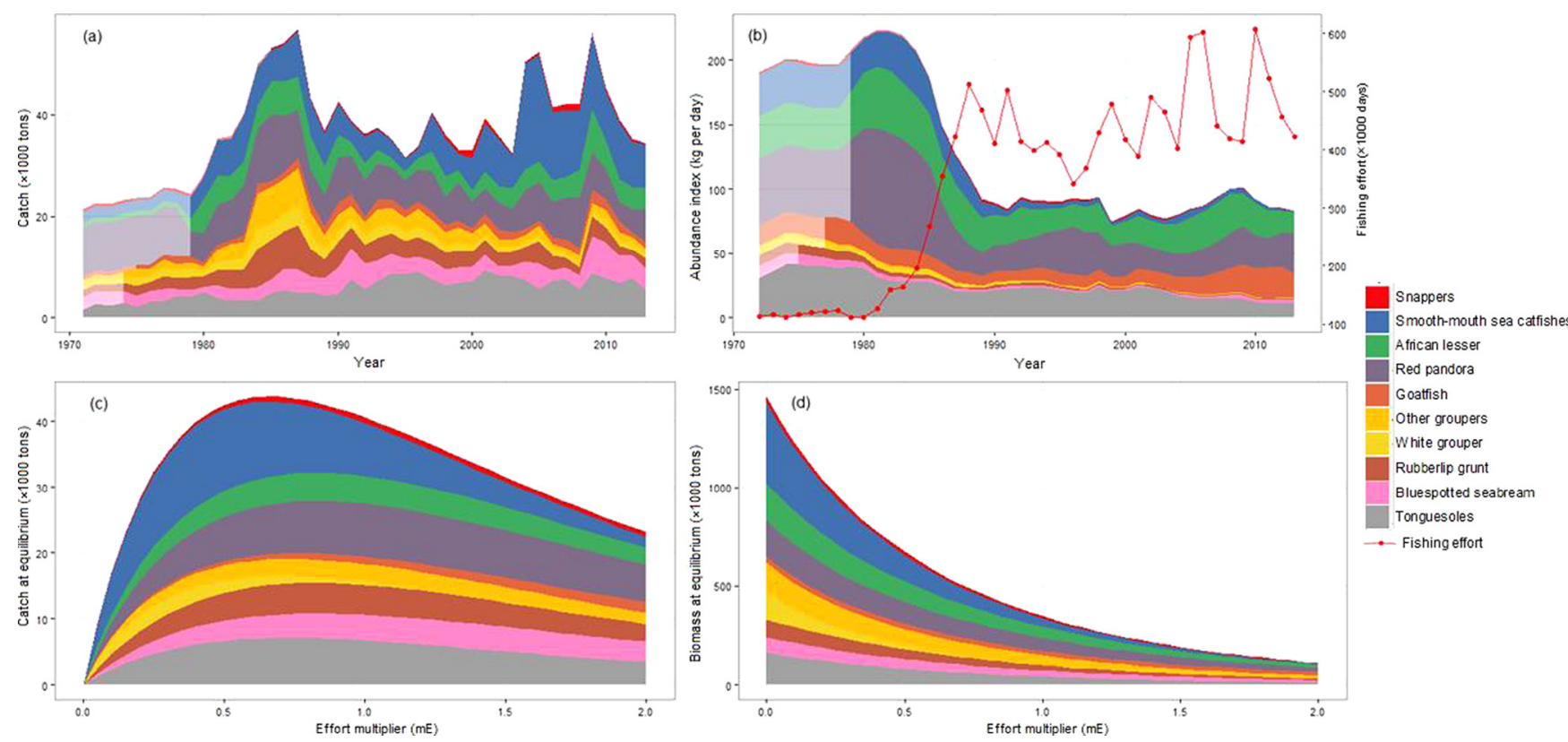

Fig. 4. Cumulated stock assessment using Bayesian dynamic production model: (a) cumulative observed catches; (b) cumulative biomasses with the effort multiplier (red line and dots) on the 2nd $y$-axis; (c) production at equilibrium and (d) biomass at equilibrium. Note that some catches and abundance indices in (a) and (b) panels have been extrapolated (lighter shade of colors) for some taxa only for graphical representation. Models and analyses did not take into account these extrapolations.

Table 2. Outputs of surplus production models are based on likelihood using deterministic approach. The parameters calculated below are: the slope of the Fox or Pella-Tomlinson model a, the intercept of the Fox or Pella-Tomlinson model b and the Pella-Tomlinson shape parameter m; the maximum sustainable yield ( $M S Y$ in tons); the fishing effort multiplier at $M S Y\left(m E_{M S Y}\right)$, the ratio of current observed yield over the maximum sustainable yield $\left(Y_{\text {cur }} / M S Y\right)$; the coefficient of determination for the functional relationship between abundance at equilibrium (derived from the Fox and Pella-Tomlinson models) and the abundance indices $R^{2}$ fun. The retained model for each species/taxa and its parameters are in bold.

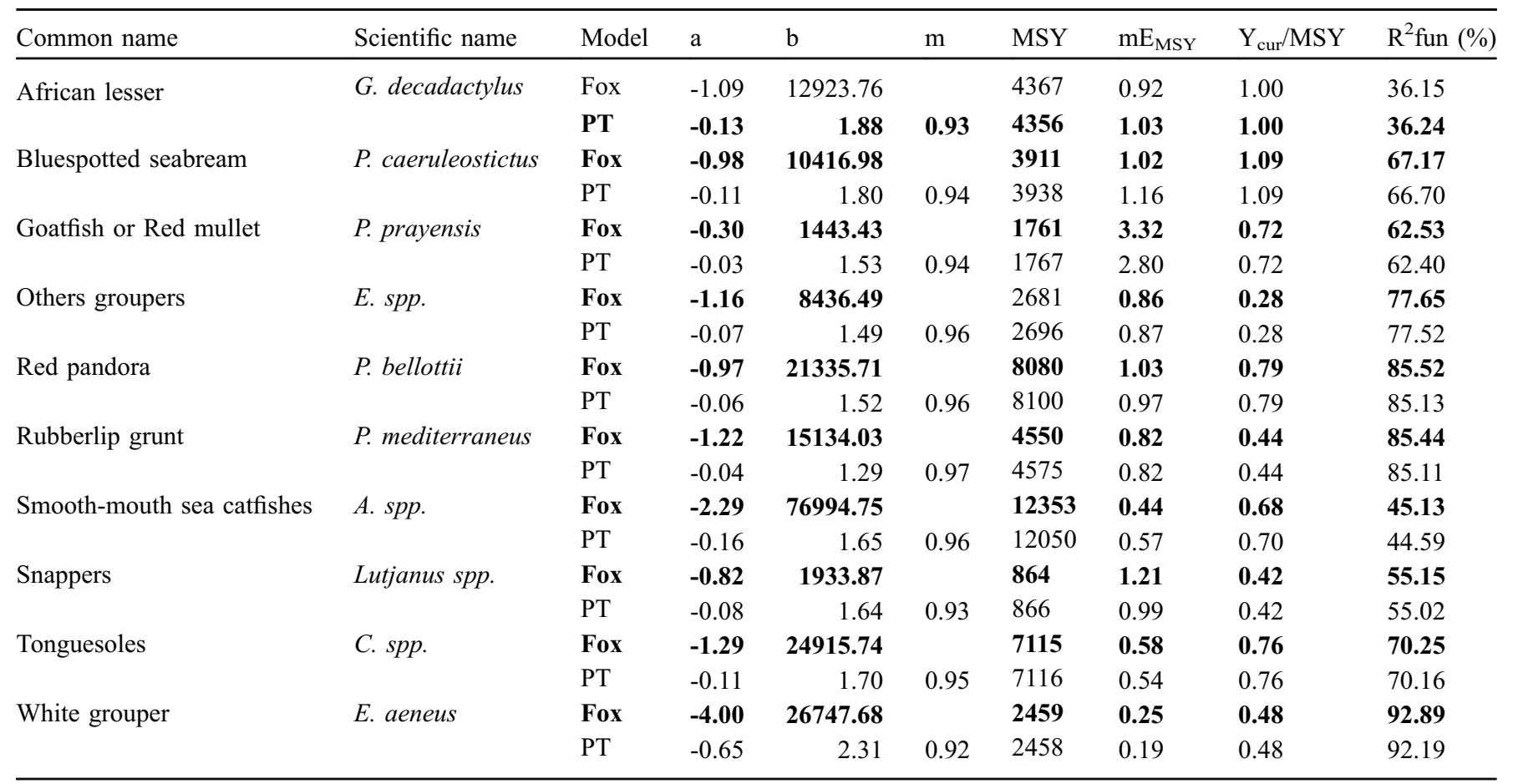


Table 3. Outputs of the dynamic production models computed in a Bayesian framework. All extracted parameters are median posterior estimate: intrinsic growth rate $\left(r\right.$ in year $\left.{ }^{-1}\right)$, catchability $(q)$, carrying capacity ( $K$ in tons), maximum sustainable yield ( $M S Y$ in tons), Biomass at $M S Y\left(B_{M S Y}\right.$ in tons), Fishing mortality at $M S Y\left(F_{M S Y}\right.$ in year $\left.{ }^{-1}\right)$, Current fishing mortality per fishing sector $\left(F_{I F}\right.$ and $F_{A F}$ for industrial and artisanal, respectively), ratio of initial biomass to carrying capacity $\left(B_{\text {start }} / K\right)$, ratio of current biomass to carrying capacity $\left(B_{2013} / K\right)$, deviance information criterion (DIC) and coefficient of determination for the dynamic biomass production model fitted to abundance indices $\left(R^{2}\right.$ dyn).

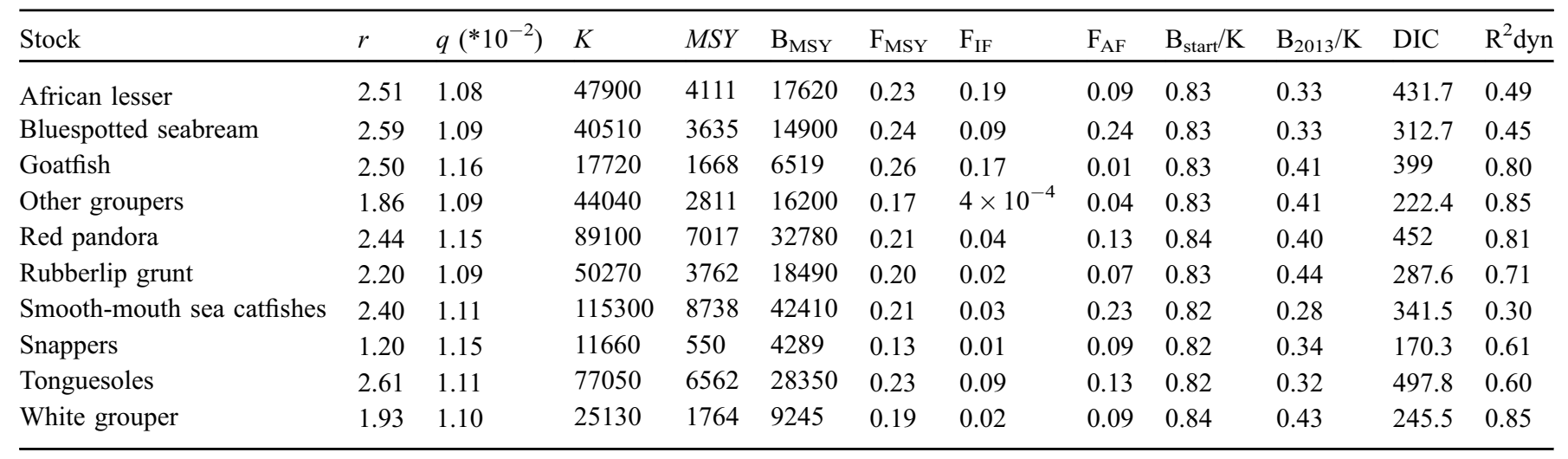

intrinsic growth rates for the 10 stocks or stock complexes were estimated between 1.2 and 2.6 and their carrying capacity was ranging from 11660 to 115300 tons with a maximum sustainable yield varying between 550 and 8738 tons. Biomass at maximum sustainable yield was estimated to be about $37 \%$ of the carrying capacity, and fishing mortality rates at maximum sustainable yield was estimated to be between 0.13 and 0.26 , considering the ten stocks. The initial proportion of biomass to carrying capacity was around 0.83 .

The models also estimated biomass and fishing mortality rates over the entire time period of catch data. For all stocks or stock complexes, the biomasses were initially near carrying capacity and have a declining trend over the time period. The biomass of the African lesser was above $B_{M S Y}$ from the $1970 \mathrm{~s}$ to the mid-1980s and during the 1995-2010 period (Fig. S2). The biomasses of the bluespotted seabream, the tonguesoles, the smooth-mouth sea catfishes and the snappers were generally remaining above $B_{M S Y}$ until 2010 while the biomass of the goatfish remained above $B_{M S Y}$ over the entire time period. The biomasses of the white grouper, the other groupers and the rubberlip grunt were high and above the $B_{M S Y}$ during the 1974-1980 period before declining steadily during the 1980s. Since 1988, their biomasses were below $B_{M S Y}$ until the recent period, around 2010. The biomass of the red pandora sharply fell down (from 75000 to 34000 tons) between the mid-1970s and 1988 before fluctuating around $B_{M S Y}$ from 1990 onwards. Fishing mortality rates experienced high year-to-year fluctuations over the time period (Fig. S3). They were initially low and steadily increased, likely exceeding $F_{M S Y}$ in mid1980 s or in 1990 depending on the stocks, except the smoothmouth sea catfishes whose ratio of $F / F_{M S Y}$ exceeded 1 from 2004 onwards.

The demersal finfish stocks have experienced different levels of fishing mortality over time. At the beginning of the exploitation, all stocks were in the safe buffer and at a few points in the history of the fisheries, overfishing have occurred (Fig. 5). The stocks of the goatfish, the red pandora, the rubberlip grunt, the white grouper and the other groupers have experienced all four situations and are now in the safe zone. But, before recovering in the 2000 s, these last three stocks were highly overfished in the mid-1980s with a fishing mortality doubling $F_{M S Y}$ (Fig. S3). The stock of goatfish was the only which experienced two situations (safe zone and experiencing overfishing). The stocks of the African lesser, the bluespotted seabream, the smooth-mouth sea catfishes and the tonguesoles are currently being overfished and overfishing is occurring. The situation of the snappers is similar to the tonguesoles except the stock is recovering (not experiencing overfishing but stay overfished).

Globally, the retrospective analysis confirms the robustness of our diagnosis (Fig. S4 and Fig. S5). No clear pattern suggesting a systematic over or underestimate of biomass is observed for most stocks. Only three stocks are exceptions (the white grouper, the other groupers, and the rubberlip grunt) exhibiting a pattern which suggests that the terminal biomass could be slightly underestimated and the terminal fishing mortality overestimated. But gaps remain limited and neither the trends over the last decade nor the global diagnoses of those stocks are changed.

The combined assessment results (Fig. 4c, d) suggest that the coastal demersal fish stocks are overexploited, with a high current fishing effort that exceeds that at $M S Y$ by around $35 \%$ $\left(m E_{M S Y}=1.35\right)$. For the altogether stocks combined, the cumulated MSY is estimated at $43800 \mathrm{t}$ compared to $34400 \mathrm{t}$ of observed catches, while the catch at equilibrium corresponding to the current fishing effort is $40600 \mathrm{t}$. The current total catch loss is thus estimated equal to $7 \%$. Considering six stocks properly identified at the species level (in contrast of that known at the genus level), combined assessment suggests an overexploitation with current fishing effort exceeding $15 \%$ of $m E_{M S Y}$ and an estimated $M S Y$ of $22500 \mathrm{t}$.

\section{Discussions}

\subsection{Decreasing abundance indices}

In this study, abundance indices estimated from scientific surveys were analyzed with those modeled from commercial CPUEs. Data from scientific surveys which have a more rigorous sampling design and protocols suffer from a low 

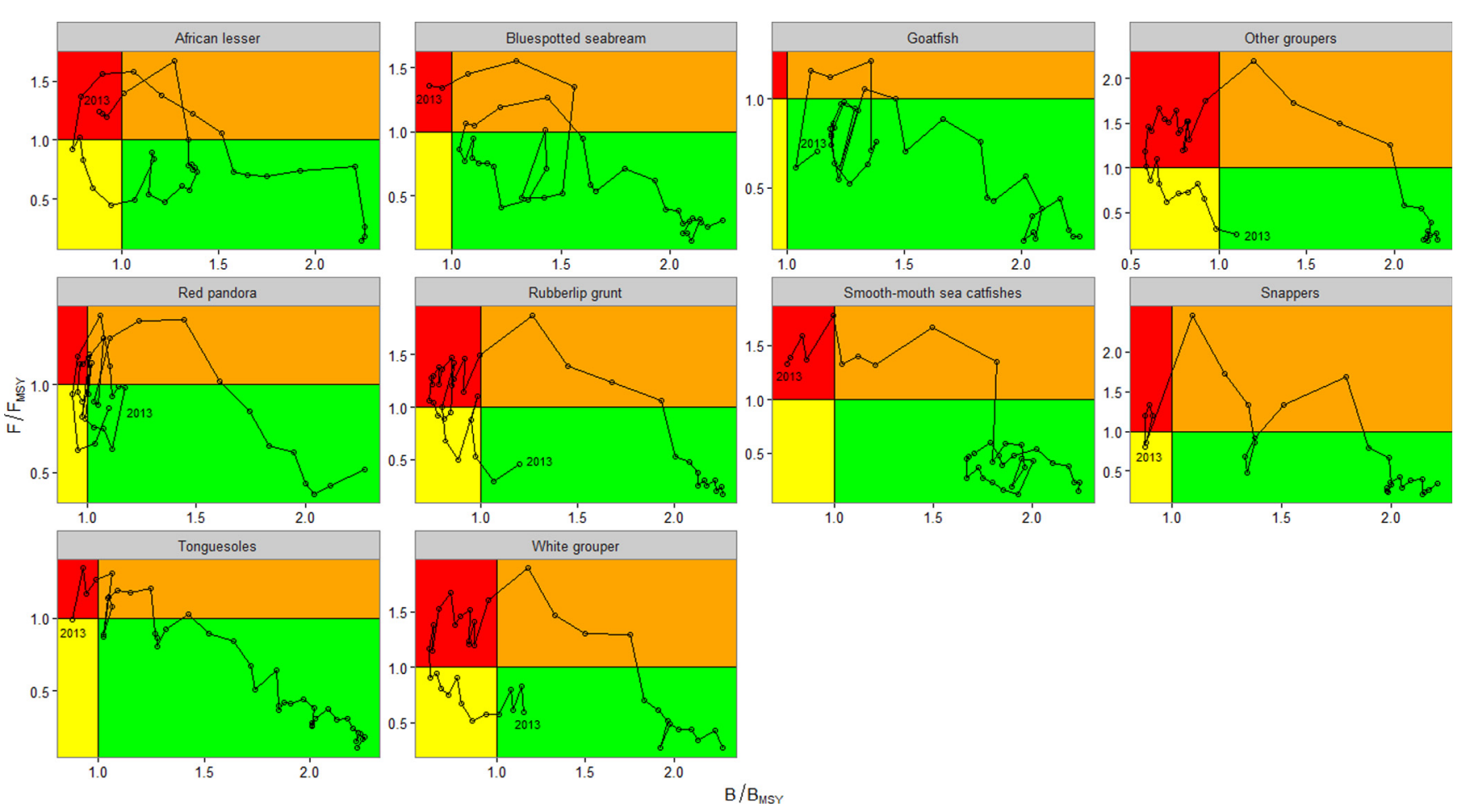

Fig. 5. Kobe plot (stock status plot) showing the estimated trajectories of the coastal demersal stocks, according to the stock status (stock underexploited or overexploited, according to $B / B M S Y$ ) and to the fishing pressure (experiencing overfishing or not, according to $F / F M S Y$ ).

sampling rate and many missing years due to the high cost of a survey (Meissa et al., 2013), especially for a developing countries such as Senegal. In contrast, the lack of direct correlation between commercial CPUEs and true abundances is a well-known problem in fishery sciences (Hilborn and Walters, 1992). In particular, changes in the fishing efficiency of commercial vessel may induce biases in estimations of abundance indices. To avoid such biases, commercial CPUEs were correlated with scientific survey abundance index and a rate of increase in fishing efficiency (alpha) was estimated for each stock.

Consistency between estimates of abundance from these two independent data sources was checked by performing sensitive analyses around fishing power rate varying between optimistic to very pessimistic values and always correlated with scientific survey. For most stocks, the abundance index estimated from scientific surveys was highly consistent with the index from industrial CPUE, except for two stocks (the snappers and the other groupers). The indices of these latter derived from small-scale fishery (fixed bottom net and simple line as fishing gear, respectively) and were corrected based on an annual $5 \%$ trend in the fishing power to get a significant correlation.

Despite sparse, survey abundance index confirmed the trend of commercial CPUEs, and showed a general decrease of fish biomasses. The change in abundance throughout the study period results from a strong increase in the fishing pressure. It can also be linked to changes in fishery strategies (Meissa et al., 2013). For instance, the fishing efforts were recently modified in the small-scale fishery, shifting to species not exploited until now, like the smooth puffer (Lagocephalus laevigatus). More recently, the beltfish (Trichiurus lepturus) fishery also developed rapidly in Kayar harbor (Fig. 1) with market demands, especially from South Korean investments in processing fish plants in Senegal directed for exports. This demand shifted fishing effort to focus its exploitation on this species for export, inducing large changes in fishermen strategies (Laloë and Samba, 1991; Fall, 2009) who used to target the demersal fishes assessed in this study.

\subsection{Global overexploitation}

The assessment of main coastal demersal stocks was performed using two model configurations (deterministic and stochastic) in parallel to test their robustness (Fonteneau et al., 1998; Gascuel, 2008; Meissa et al., 2013). Regarding the dynamic production models fitted in a Bayesian framework, several studies demonstrated that the use of two uncertainty sources, one related to the process error and the other to the observation error generates less biased estimations (Punt and Hilborn, 1997; McAllister et al., 2001; Punt, 2003; Ono et al., 2012; Meissa et al., 2013).

Both models (dynamic or based on a pseudo-equilibrium assumption) have produced slightly different results, but both exhibiting an overall overexploitation status of the resources and the reduction of the total demersal biomass. The demersal finfish stocks have individually experienced different levels of fishing mortality over time. The stocks of the rubberlip grunt, the white grouper and the other groupers were highly overfished in the mid-1980s, as stated in previous stock assessments in Senegal 10 years ago (Gascuel and Ménard, 1997; Barry et al., 2002; Gascuel et al., 2003; Laurans, 2005). The stocks of the African lesser, the bluespotted seabream, the 
smooth-mouth sea catfishes and the tonguesoles are currently being overfished and overfishing is still occurring. The stock of the snappers stay overfished but is no more experiencing overfishing.

This alarming situation was already noted a decade ago by Laurans (2005) for the white grouper; and more recently by (Meissa et al., 2013) in Mauritania, a neighboring country with whom some stocks might share the same spatial and seasonal distribution pattern (Gascuel and Ménard, 1997). These studies demonstrated that coastal demersal stocks in Senegal have experienced heavy exploitation during the past 30 years. Our study confirmed once again these alarming conclusions.

However, since 2006, decline in total biomass has stabilized at low levels while for few other species such as the goatfish, the red pandora and the bluespotted seabream, an increase of abundance is observed but does not reverse the overall overexploitation of these resources. The improvement is probably due to the change of fishing strategy and the withdrawal of the European fleets after the end of EU-Senegal fishing agreement in 2006 suggesting that the number of legally operating foreign industrial vessels has decreased (Belhabib et al., 2014).

Despite the ecosystem of the Senegalese continental shelf being in a poor status and relatively stable (Coll et al., 2016), the effects of fishing are likely to be enhanced with ecosystem changes. These should be related to the coastal upwelling occurring in spring in the Senegalese continental shelf and to environmentally induced shifts, influencing the abundance and distribution of these key resources (Roy et al., 2002; Chavance et al., 2004).

\section{Conclusion}

Most of the recent fish stock assessments performed in Senegal used to determine the status of the stocks of the five main demersal stocks (the white grouper, the red pandora, the bluespotted seabream, the African lesser and the goatfish), revealed a serious situation of exploitation. Other demersal fish stocks were shown to experience similar situation of heavy exploitation. As in Mauritania, where 22 stocks were assessed using dynamic production models in a Bayesian framework and ecosystem based indicators (Meissa and Gascuel, 2014), 10 stocks were assessed in this study (the half of demersal landings), using single-species stock assessment first, then combined assessment. These analyses highlighted an overall level of overexploitation of demersal stocks whether the stochastic or deterministic approach is used. The most overfished and depleted stocks should be prioritized in the implementation of closed fishing season and the monitoring of fishing regulations. This study suggests that a drastic measure, such as a moratorium to catch and land some species, should be considered.

As for most of African countries, Senegalese fisheries management plans are still based on species-specific and cover only few high commercial value species such as octopus and deep-water shrimp. In addition, this approach lacks the participation of stakeholders and adaptation measures with public consultation. However, the Ministry of Fisheries is in the process of implementing a co-management strategies based on a stakeholders-input through a system known as Councils of
Local Artisanal Fisheries, called in French "Conseils Locaux de Pêche Artisanale". These species-specific fisheries management plans and/or policies (each addressing specific resources and fisheries) can lead to frequent and uncontrolled redistribution of fishing efforts, from targeted and monitored resources to other ones, less or not monitored with adverse and unforeseen knock-on effects on other ecosystem components. (Hilborn, 2007; Leslie and McLeod, 2007; Fulton et al., 2011). Instead of implementing a species based management, an ecosystem approach to fisheries management (EAFM) should be implemented to take into account all ecosystem components. According to (Gascuel et al., 2014), if we decide to implement such an EAFM, we have to: (i) establish an ecosystem health diagnosis and regularly update them, (ii) assess and monitor environmental impacts and socio-economic performance of fleets, and (iii) set up, monitor and update ecosystem and bio-economic models for advice-oriented purposes. Obviously necessary, EAFM must take the challenge of introducing a system of monitoring and assessing all components of the fisheries and the ecosystem by using robust indicators that will help to identify the most vulnerable species and those endangered.

Acknowledgement. We would like to thank the editor and two anonymous reviewers for their insightful comments on the manuscript and their very useful suggestions, which significantly improved its quality. We are also grateful to ADUPES (Aménagement Durable des Pêcheries du Sénégal) project funded by the Senegalese Government and European Union (10th FED) which supported this work.

\section{References}

Arrizabalaga H, Murua M, Majkowski J. 2012. Global status of tuna stocks: summary sheets. Rev Invest Mar 19: 645-676.

Ba K, Thiaw M, Lazar N, Sarr A, Brochier T, Ndiaye I, Faye A, Sadio O, Panfili J, Thiaw OT, Brehmer P. 2016. Resilience of Key Biological parameters of the Senegalese flat Sardinella to overfishing and climate change. PLoS ONE11: e0156143.

Barry M, Laurans M, Thiao D, Gascuel D. 2002. Diagnostic de l'état d'exploitation de cinq espèces démersales côtières sénégalaises, in: Chavance et al. (Eds.), Pêcheries Maritimes, Écosystèmes et Sociétés En Afrique de l'Ouest: Un demi-siècle de changement. Edition Office des Communautés Européennes, Coll Rap de recherche halieutique ACP-UE n 15, Luxembourg, pp. 183-194.

Belhabib D, Koutob V, Sall A, Lam VWY, Pauly D. 2014. Fisheries catch misreporting and its implications: the case of Senegal. Fish Res 151: 1-11.

Bolker BM. 2008. Ecological models and data in R, Princeton University Press, USA.

Brooks SP, Gelman A. 1998. General methods for monitoring convergence of iterative simulations. JComputGraphStat7:434-455.

CECAF. 2012. Report of the FAO/CECAF Working Group on the Assessment of Demersal Resources-Subgroup North Banjul, the Gambia, 6-14 November 2007, 10/71. Banjul, The Gambia, Programme for the development of fisheries in the Eastern Central Atlantic, Fishery Committee for the Eastern Central Atlantic.

Chavance P, Bâ M, Gascuel D, Vakily JM, Pauly D. 2004. Pêcheries maritimes, écosystèmes \& sociétés en Afrique de l'Ouest: Un demi-siècle de changement [Marine Fisheries, Ecosystems and Societies in West Africa: half a century of change], actes du symposium international, Dakar (Sénégal), 24-28 Juin 2002, 
Bruxelles, Office des publications officielles des Communautés européennes, XXXVI-532-XIV p., 6 pl. h.-t. coul., coll. Rapports de recherche halieutique A.C.P.-U.E., No. 15.

Christensen V, Amorim P, Diallo I, Diouf T, Guénette S, Heymans JJ, Samb B, Stobberup K, Vakily JM, Vasconcellos M. 2004. Trends in fish biomass off Northwest Africa, 1960-2000. Fish Cent Res Rep 12: 215-220.

Coll M, Shannon LJ, Kleisner KM, Juan-Jordá MJ, et al. 2016. Ecological indicators to capture the effects of fishing on biodiversity and conservation status of marine ecosystems. Ecol Ind 60: 947-962.

Fall M. 2009. Pêcherie démersale côtière au Sénégal: essai de modélisation de la dynamique de l'exploitation des stocks, Doctorat de l'Université Montpellier 2, Montpellier, France.

Faure V, Inejih AC, Demarq H, Cury P. 2000. The importance of retention processes in upwelling areas for recruitment of Octopus vulgaris: the example of the Arguin Bank (Mauritania). Fish Oceanogr 9: 343-355.

Fonteneau A, Gascuel D, Pallares P. 1998. Vingt-cinq ans d'évaluation des ressources thonières de l'Atlantique: quelques réflexions méthodologiques. Collect Vol Sci Pap Int Comm Conserv Atl Tunas 50: 523-562.

Fox WW. 1970. An exponential surplus-yield model for optimizing exploited fish populations. T Am Fish Soc 99: 80-88.

Fox WW. 1975. Fitting the generalized stock production model by least-squares and equilibrium approximation. Fish Bull 73: 23-37.

Fulton EA, Link JS, Kaplan IC, Savina-Rolland M, Johnson P, Ainsworth C, Horne P, Gorton R, Gamble RJ, Smith ADM, Smith DC. 2011. Lessons in modelling and management of marine ecosystems: the Atlantis experience. Fish Fish 12: 171-188.

Garcia S, Lhomme F, Chabanne J. 1979. La pêche démersale au Sénégal: historique et potentiel, in: Groupe de Travail Ad hoc sur les stocks cotiers de démersaux vivant entre le sud de la Mauritanie et le Libéria (Ed.), Rapport du groupe de travail Ad hoc sur les stocks démersaux vivant entre le sud de la Mauritanie et le Libéria, FAO, Rome, pp. 59-77.

Gascuel D. 2008. Dynamique des populations et gestion des stocks halieutiques, Support de cours, Agrocampus Ouest/Campus numérique ENVAM éd., Rennes, France, 125 p.

Gascuel D, Ménard F. 1997. Assessment of a multispecies fishery in Senegal, using production models and diversity indices. Aquat Living Resour 10: 281-288.

Gascuel D, Fonteneau A, Foucher E. 1993. Analyse de l'évolution des puissances de pêche par l"analyse des cohortes: application aux senneurs exploitant 1"albacore (Thunnus albacares) dans 1"Atlantique Est. Aquat Living Resour 6: 15-30.

Gascuel D, Barry M, Laurans M, Sidibé A, (eds). 2003. Evaluations des stocks démersaux en Afrique du Nord-Ouest, Travaux du groupe "Analyses monospécifiques" du projet SIAP, COPACE/ PACE Serie, n 03/65, Rome, FAO, 108 p.

Gascuel D, Laurans M, Sidibé A, Barry MD. 2004. Diagnostic comparatif de l'état des stocks et évolutions d'abondance des ressources démersales dans les pays de la CSRP. In: Chavance P. et al (éds), Pêcheries Maritimes, Ecosystems et Sociétés En Afrique de l'Ouest: Un Demi-Siècle de Changement. Edition Office des Communautés Européennes, Coll Rap de recherche halieutique ACP-UE n 15, Luxembourg, pp. 205-222.

Gascuel D, Labrosse P, Meissa B, Taleb Sidi MO, Guénette S. 2007. Decline of demersal resources in North-West Africa: an analysis of Mauritanian trawl survey data over the last 25 years. Afr J Mar Sci 29: $331-345$.

Gascuel D, Coll M, Fox C, Guénette S, Guitton J, Kenny A, Knittweis L, Nielsen JR, Piet G, Raid T, Travers-Trolet M, Shephard S. 2014.
Fishing impact and environmental status in European seas: a diagnosis from stock assessments and ecosystem indicators. Fish Fish 17: 31-55.

Gislason H, Rice J. 1998. Modelling the response of size and diversity spectra of fish assemblages to changes in exploitation. ICES J Mar Sci 55: 362-370.

Harwood J, Stokes K. 2003. Coping with uncertainty in ecological advice: lessons from fisheries. Trends Ecol Evol 18: 617-622.

Hilborn R. 2007. Managing fisheries is managing people: what has been learned? Fish Fish 8: 285-296.

Hilborn R, Liermann M. 1998. Standing on the shoulders of giants: learning from experience in fisheries. Rev Fish Biol Fisher 8: 273 283.

Hilborn R, Walters CJ. 1992. Quantitative fisheries stock assessment: choice, dynamics and uncertainty. Rev Fish Biol Fisher 2: 177-178.

Jensen AL. 2005. Harvest in a fluctuating environment and conservative harvest for the Fox surplus production model. Ecol Model 182: 1-9.

Laloë F, Samba A. 1991. A simulation model of artisanal fisheries of Senegal. ICES Mar Sci Symp 193: 281-286.

Laurans M. 2005. Ressources et exploitations " démersales ” en Afrique de l'ouest: evaluation des stocks, dynamique des populations et approche écosystémique, Doctorat de l'École nationale supérieure agronomique de Rennes, $311 \mathrm{p}$.

Laurans M, Barry M, Gascuel D. 2003. Diagnostics de cinq stocks sénégalais par l'approche globale (Galeoides decadactylus, Pagellus bellottii, Pseudupeneus prayensis, Sparus caeruleostictus, Epinephelus aeneus), in : D. Gascuel, et al. (Ed.), Evaluations des stocks démersaux en Afrique du Nord-Ouest, travaux du groupe "Analyses mono-spécifiques" du projet SIAP. COPACE/ PACE Series, Rome, FAO, 03/65, pp. 19-28.

Laurans M, Gascuel D, Chassot E, Thiam D. 2004. Changes in the trophic structure of fish demersal communities in West Africa in the three last decades. Aquat Living Resour 17: 163-173.

Laurent AG. 1963. The Lognormal distribution and the translation method: description and estimation problems. J Am Stat Assoc 58: 231-235.

Legault CM. 2009. Report of the Retrospective Working Group, January 14-16, US Dept Commer, Northeast Fish Sci Cent. 09-01, Woods Hole, Massachusetts, 2008, 30 p.

Leslie HM, McLeod KL. 2007. Confronting the challenges of implementing marine ecosystem-based management. Front Ecol Environ 5: 540-548.

McAllister MK, Kirkwood GP. 1998. Bayesian stock assessment: a review and example application using the logistic model. ICES J Mar Sci 55: 1031-1060.

McAllister MK, Pikitch EK, Babcock EA. 2001. Using demographic methods to construct Bayesian priors for the intrinsic rate of increase in the Schaefer model and implications for stock rebuilding. Can J Fish Aquat Sci 58: 1871-1890.

Meissa B, Gascuel D. 2014. Overfishing of marine resources: some lessons from the assessment of demersal stocks off Mauritania. ICES J Mar Sci 72: 414-427.

Meissa B, Gascuel D, Rivot E. 2013. Assessing stocks in data-poor African fisheries: a case study on the white grouper Epinephelus aeneus of Mauritania. Afr J Mar Sci 35: 253-267.

Meissa B, Fall M, Thiam N, Thiaw M, Ba K, Sarr JMA, Thiam M, Ngom F. 2016. Évaluation des principaux stocks demersaux exploités au Sénégal Programme Aménagement Durable des Pêches au Sénégal (ADUPES), note technique no 2, Centre de Recherches Océanographiques de Dakar-Thiaroye.

Meyer R, Millar RB. 1999. BUGS in Bayesian stock assessments. Can J Fish Aquat Sci 56: 1078-1087. 
Ono K, Punt AE, Rivot E. 2012. Model performance analysis for Bayesian biomass dynamics models using bias, precision and reliability metrics. Fish Res 125-126: 173-183.

Parent E, Rivot E. 2012. Introduction to hierarchical Bayesian modeling for ecological data, CRC Press, Florida, USA.

Pella JJ, Tomlinson PK. 1969. A generalized stock production model. Inter-Am Trop Tuna Comm Bull 13: 416-497.

Punt AE. 2003. Extending production models to include process error in the population dynamics. Can J Fish Aquat Sci 60: 1217-1228.

Punt AE, Hilborn R. 1997. Fisheries stock assessment and decision analysis: the Bayesian approach. Rev Fish Biol Fisher 7: 35-63.

Robert M, Faraj A, McAllister MK, Rivot E. 2010. Bayesian statespace modelling of the De Lury depletion model: strengths and limitations of the method, and application to the Moroccan octopus fishery. ICES J Mar Sci 67: 1272-1290.

Roy C, Cury P, Fréon P, Demarcq H. 2002. Environmental and resource variability off Northwest Africa and in the Gulf of Guinea: review, in: J.M. McGlade, P. Cury, K.A. Koranteng, N.J. Hardman-Mountford (Eds.), The Gulf of Guinea Large Marine Ecosystem: Environmental Forcing and Sustainable Development of Marine Resources, Elsevier, Amsterdam, pp. 121-139.

Schaefer MB. 1991. Some aspects of the dynamics of populations important to the management of the commercial marine fisheries. Bull Math Biol 53: 253-279.

Stefánsson G. 1996. Analysis of groundfish survey abundance data: combining the GLM and delta approaches. ICES J Mar Sci 53: $577-588$.

Thiam N, Thiaw M, Fall M. 2014. Evaluation directe des stocks halieutiques démersaux côtiers dans la ZEE du Sénégal, Document no 1 du Programme Aménagement Durable des Pêches au Sénégal (ADUPES), Centre de Recherches Océanographiques de Dakar-Thiaroye.

Thiam N, Thiaw M, Fall M. 2016. Rapport de la campagne de chalutages démersaux côtiers, Document no 2 du Programme Aménagement Durable des Pêches au Sénégal (ADUPES), Centre de Recherches Océanographiques de Dakar-Thiaroye.

Thiao D, Chaboud C, Samba A, Laloë F, Cury P. 2012. Economic dimension of the collapse of the "false cod" Epinephelus aeneus in a context of ineffective management of the small-scale fisheries in Senegal, African J Marin Sci 34: 305-311.

Thiaw M. 2010. Dynamique des ressources halieutiques à durée de vie courte: cas des stocks de pulpe et de crevettes exploités au Sénégal, Doctorat Agrocampus Ouest, Rennes, 215 p.

Thiaw M, Gascuel D, Jouffre D, Thiaw OT. 2009. A surplus production model including environmental effects: application to the Senegalese white shrimp stocks. Prog Oceanogr 83: 351360.

Thiaw M, Ba K, Fall M, Thiam N, Thiam M, Jouffre D. 2015. Evaluation des principaux stocks démersaux exploités au Sénégal, Programme Aménagement Durable des Pêches au Sénégal (ADUPES), note technique no 1, Centre de Recherches Océanographiques de Dakar-Thiaroye, Dakar, Sénégal, 35 p.

Walters C, Ludwig D. 1994. Calculation of bayes posterior probability distributions for key population parameters. Can $J$ Fish Aquat Sci 51: 713-722.

Yau AJY, Chang YJ, Brodziak J. 2014. Stock assessment of swordfish (Xiphias gladius) in the Eastern Pacific Ocean through2012, International Scientific Committee for Tuna and Tuna-like Species in the North Pacific Ocean, Billfish Working Group Workshop, 16-22 July 2014, Taipei, Chinese-Taipei, 86 p.

Cite this article as: Ba K, Thiaw M, Fall M, Thiam N, Meissa B, Jouffre D, Thiaw OT, Gascuel D. 2018. Long-term fishing impact on the Senegalese coastal demersal resources: diagnosing from stock assessment models. Aquat. Living Resour. 31: 8 